\title{
X/XY CHROMOSOME MOSAICISM: TURNER SYNDROME AND OTHER CLINICAL CONDITIONS
}

\author{
Irena Andriuškevičiūtè, Loreta Šalomskienè, Lina Jurkènienè, and Algimantas Sinkus
}

Department of Biology, Kaunas University of Medicine, 9 A. Mickevičiaus Street, Kaunas, LT-44307, LITHUANIA

E-mail: ireandr@vision.kmu.It

Communicated by İzaks Rašals

The 45, $X / 46, X Y$ mosaicism shows a wide spectrum of phenotypes ranging from females with Turner syndrome, male or female pseudohermaphroditism, to appearently normal male development. Chromosome anomalies accompanying Turner syndrome were found in lymphocyte cultures of 236 patients. Chromosomal analysis revealed the karyotype 45,X in 118 (50.0\%) patients. $X$ monosomy mosaics or structural rearrangements of the $X$ chromosome was established in $112(47.5 \%)$ patients. The $Y$ chromosome was found in six (2.5\%) patients with typical features of Turner syndrome. In five mosaics $45, X / 46, X Y$ the proportion of the $X Y$ clone ranged from $46 \%$ to $76 \%$. In one Turner syndrome patient only $47, X Y Y$ cells were found (solely blood culture investigated). In most cases of $45, X / 46, X Y$ mosaicism, the cause is considered to be the loss of the $Y$ chromosome because of nondisjunction after normal disomic fertilisation. Five other patients with $X / X Y$ chromosome mosaicism showed mixed gonadal dysgenesis (two patients), one male pseudohermafroditism, one male with Pierre Robin syndrome, and one normal male phenotype. In two non Turner syndrome patients nondisjunction of the primary clone 46, $X Y$ was obvious and resulted in mosaicism 45, $X / 46, X Y / 47, X Y Y$, the one patient contained dicentric $Y$. The similarities between $X / X Y$ Turner syndrome and other nosological entity of females possessing $Y$ chromosome - the Swyer syndrome - are discussed.

Key words: Turner syndrome, $Y$ chromosome, chromosome mosaicism.

\section{INTRODUCTION}

Genetic sex in humans is determined by the chromosomal set, which is usually in females $46, \mathrm{XX}$, and in males $46, \mathrm{XY}$. This chromosomal pattern leads to a cascade of genetic events, which ends in the development of male (Hiort and Holterhus, 2000; Kučinskas and Just, 2005) or female (Heikkila et al., 2000) gonads and the secondary sexual characteristics. Our scholastic knowledge about the XX-XY mechanism of sex inheritance was considerably enlarged by investigations of XX (female to male) and XY (male to female) sex-reversal patients. The testis-determining pathway is much better known than the ovary pathway (Cotinot et al., 2002). The Swyer syndrome (XY women) is known, in which typical signs are gonadal dysgenesis (female phenotype without extragenital symptomatics), gonadoblastoma and familial recurrence. In our previous report (Just et al., 2007) one of three affected XY-sisters was suffering from gonadoblastoma. The $\mathrm{Y}$ chromosome sometimes is found in patients with Turner syndrome and in intersexual patients as well. The present investigation embraces the patients in which chromosome mosaicism $45, \mathrm{X} / 46, \mathrm{XY}$ is found. The aim of the investigation is to discuss the literature and author's own findings, which can explain why the presence of male Y chromosome causes very different phenotypes.

\section{SUBJECTS AND METHODS}

During the years 1970-2005, in our laboratory of cytogenetics 1,271 patients with suspected Turner syndrome were investigated. The patients were referred mainly by gynecologists (primary or secondary amenorrhoea), endocrinologists (delayed sexual maturation), pediatricians (short body stature), and also by other physicians. Three-day lymphocyte cultures with phytohaemagglutinin-treated capillary or venous blood after standard colcemide and $\mathrm{KCl}$-hypotonic procedures were fixed and stained by $\mathrm{G}$ and $\mathrm{Q}$ bands (Rooney, 2001). In each cell culture at least 100 metaphases were analysed.

In our previous study (Just et al., 2007) the SRY open reading frame and flanking sequences were PCR-amplified and sequenced including the functional promoter of SRY ( $\mathrm{Su}$ and Lau, 1993; Hossain and Saunders, 2001). 


\section{RESULTS}

Chromosome anomalies accompanying Turner syndrome were found in 236 patients (Table 1). Half of them possessed 45 chromosomes due to the X monosomy in all cells. The another half contained $\mathrm{X}$ monosomy only in part of the cells (chromosome mosaicism 45,X/46, XX in 27 patients) or structural rearrangements of $\mathrm{X}$ chromosome-ring, isochromosome Xq (frequent) or Xp (rare), deletions of long or short arm. The structural rearrangements were frequently combined with cell lines possessing normal karyotype or $\mathrm{X}$ monosomy. We established three different cell lines in some patients, and in one patient - four cell lines: 45,X/46,X $\mathrm{r}(\mathrm{X}), 46, \mathrm{X}, \mathrm{i}(\mathrm{Xq}), 47, \mathrm{X}, \mathrm{i}(\mathrm{Xq}), \mathrm{i}(\mathrm{Xq})$, i.e. $\mathrm{X}$ monosomy, ring $\mathrm{X}$ chromosome, isochromosome $\mathrm{Xq}$, two isochromosomes Xq. In two patients, alongside a monosomic cell line, a cell line with autosomal abberation was found - in one patient ring chromosome 20, in other - the 13q21q Robertsonian translocation. In six Turner syndrome patients $(2.5 \%)$ the Y chromosome was found (patients Nos.1-6, Table 2). Patient 6 possessed only 47, XYY cells - a unique cytological condition in Turner syndrome. In this patient (like others) solely blood leucocytes were investigated. At the age of 14 she lacked breasts and also menses (body height $145 \mathrm{~cm}$ ), and endocrinologists undoubtedly established the diagnosis of Turner syndrome.

Table 1

KARYOTYPE IN 236 TURNER SYNDROME PATIENTS

\begin{tabular}{ll|c|c}
\hline \multirow{2}{*}{ Chromosome constitution } & \multicolumn{2}{|c}{ Patients } \\
\cline { 3 - 4 } & $n$ & $\%$ \\
\hline 1. $45, \mathrm{X}$ & 118 & 50.0 \\
2. & $45, \mathrm{X} / 46, \mathrm{XX}$ mosaics or /and & & \\
& structural X-rearrangements & 112 & 47.5 \\
3. 45,X/46,XY & 6 & 2.5 \\
& Total & 236 & 100.0
\end{tabular}

Table 2

KARYOTYPE AND CLINICAL FEATURES IN 11 PATIENTS WITH X/XY CHROMOSOME MOSAICISM

\begin{tabular}{|c|c|c|c|c|}
\hline $\begin{array}{l}\text { Patient } \\
\text { No. }\end{array}$ & $\begin{array}{c}\text { Age } \\
\text { (years) }\end{array}$ & Karyotype & $\begin{array}{c}\text { Ratio of } \\
\text { cell lines } \\
(\text { in } \%)\end{array}$ & Clinical diagnosis \\
\hline 1 & 23 & $45, X / 46, X Y$ & $30 / 70$ & Turner syndrome \\
\hline 2 & 23 & $45, \mathrm{X} / 46, \mathrm{XY}$ & $54 / 46$ & Turner syndrome \\
\hline 3 & 15 & $45, \mathrm{X} / 46, \mathrm{XY}$ & $24 / 76$ & Turner syndrome \\
\hline 4 & 16 & $45, \mathrm{X} / 46, \mathrm{XY}$ & $50 / 50$ & Turner syndrome \\
\hline 5 & 50 & $45, X / 46, X Y$ & $42 / 58$ & Turner syndrome \\
\hline 6 & 14 & 47,XYY & 100 & Turner syndrome \\
\hline 7 & 19 & $45, \mathrm{X} / 46, \mathrm{XY}$ & $40 / 60$ & $\begin{array}{l}\text { Male } \\
\text { pseudohermaphroditism }\end{array}$ \\
\hline 8 & 2 & 45,X/46,X,idic(Y) & $52 / 48$ & $\begin{array}{l}\text { Mixed gonadal } \\
\text { dysgenesis }\end{array}$ \\
\hline 9 & 0 & 45,X/46,XY/47,XYY & $43 / 47 / 10$ & $\begin{array}{l}\text { Mixed gonadal } \\
\text { dysgenesis }\end{array}$ \\
\hline 10 & 14 & $45, \mathrm{X} / 46, \mathrm{XY} / 47, \mathrm{XYY}$ & $8 / 69 / 23$ & Normal male \\
\hline 11 & 0 & $45, \mathrm{X} / 46, \mathrm{XY}$ & $49 / 51$ & $\begin{array}{l}\text { Male with Pierre Robin } \\
\text { syndrome }\end{array}$ \\
\hline
\end{tabular}

Another five patients (Table 2, Nos. 7-11), possessed both $\mathrm{X}$ monosomy and $\mathrm{Y}$ chromosome cell lines showing other clinical features. These patients were investigated karyologically because of gonadal (non-Turner syndrome) pathology in infants or their karyotype anomalies were accidental diagnostic findings. Patient 7 suffered from male pseudohermaphroditism. Patients 8 and 9 suffered from mixed gonadal dysgenesis. Two of these patients possessed a cell line with double doses of chromosome Y. Patient 10 with three cell clones 45,X/46,XY/47,XYY was examined at the age of 12 years because he was the offspring of a carrier of balanced Robertsonian translocation (Idzelienè et al., 2005). His physical, mental and sexual development was corresponding to his age, and he made good progress in the general education school. At the age of 30, he had already been married and had two healthy babies. Patient 11 was suffering from Pierre Robin syndrome combined with a $\mathrm{X} / \mathrm{XY}$ karyotype. His body resembled a frog-like posture, the tonus of muscles was low, reflexes were sluggish and there was a tremour of legs and especially of arms. The tongue was large, and because of glossoptosis apnoea occurred several times per day. This symptom was the main feature in diagnosing the Pierre Robin syndrome. He choked, did not swallow, and so he had been fed with a probe and parenterally. At two weeks of age he weighed $2600 \mathrm{~g}$, and at two months - $2900 \mathrm{~g}$.

\section{DISCUSSION}

Turner syndrome is one of the most common chromosomal abnormalities in humans. It is present in $1: 2,000$ live-borns with female phenotype. These patients show an extremely variable phenotype but the most common clinical manifestations are short body stature and gonadal dysgenesis. Using cytogenetic techniques, the syndrome was characterised as an $\mathrm{X}$ chromosome monosomy $(45, \mathrm{X})$ in phenotypically female patients. This karyotype is responsible for $50 \%$ to $60 \%$ of Turner syndrome cases. Another part of karyotypes is represented by $\mathrm{X}$ monosomy combined with cell lines having a normal female karyotype $46, \mathrm{XX}$, the so-called chromosome mosaics 45,X/46,XX. Variety of structural X chromosome aberrations are known, which cause not total but partial X monosomy — ring chromosome, isochromosome of one arm, also frequently accompanied by chromosome mosaicism, when other cell line is monosomic or eusomic. The remaining 4-6\% of karyotypes in Turner syndrome patients contains $\mathrm{Y}$, the male sex chromosome. These patients usually are mosaics $45, \mathrm{X} / 46, \mathrm{XY}$. The primary cell line in the zygote of such individuals must be normal male 46,XY. The origin of the monosomic cell line is the loss of Y chromosome following mitotic nondisjunction after normal disomic fertilisation. There is ongoing discussion on the role of the magnitude of the Y-cell line in mosaics on the level of virilisation. The findings suggest that the proportion of cell lines in different tissues may determine their normal or abnormal development. It has been proposed that the 45,X cell line possesses a more apparent influence upon the phenotype than does the Y chromosome (Hsu, 1994). But the 
discrepancies in individual cell lines between the lymphocytes and other tissues do exist. Our patient 6 in this report shows a karyotype 47,XYY in all cells. But solely leucocytes from him (as also by other patients) were investigated. She must possess solely the 45 , X cells hidden in other tissues. We suppose that the presence of geographical mosaicism (when monosomic cell line 45, $\mathrm{X}$ is not found in blood cells) does exist in other tissues. Usually no correlation between the proportion of the $45, \mathrm{X} / 46, \mathrm{XY}$ cell lines in the blood or the fibroblasts was found. Differences of individual cells were shown between the lymphocytes and the gonads (Hsieh et al., 2002) Also, mosaic clones in the different gonadal cell types have been examined (Reddy and Sulcova, 1998). Phenotype of patients with mosaicism was associated with the individual proportions of gonadal cell lines. Unfortunatelly, the gonad karyotype was not yet performed routinely.

The mitotic nondisjunction is obvious when alongside with the normal male cell line $46, \mathrm{XY}$ also exist both aneuploid cell lines (like in patients 9 and 10, where all three cell clones - monosomic, eusomic and trisomic - were found in leucocytes). The primary chromosome constitution for those patients was undoubtedly 46,XY (normal male karyotype), and after mitotic nondisjunction of $\mathrm{Y}$ chromosome the monosomic clone without chromosome $\mathrm{Y}$ and the trisomic clone with double $\mathrm{Y}$ appeared. The $\mathrm{X}$ monosomic cell line in patient 10 was found only in $8 \%$ of blood cells and possibly therefore the normal male phenotype was not influenced. It is most probable that the Pierre Robin syndrome combination with $\mathrm{X}$ monosomy in patient 11 is accidental. Pierre Robin syndrome - characterised by micrognathia, cleft palate, glossoptosis - occurs both isolated or jointly with other syndromes or inborn malformations. Isolated cases always are sporadic, whereas inheritance of combined cases most often is autosomal recessive, although undoubtedly a multifactorial component is also present.

The clinical features in X-monosomic Turner syndrome patients must be determined by the losing of genes, localised in the pseudoautosomic region of both sex chromosomes either X or Y. When the normal male sex chromosomes XY are present in part of the cells, the virilisation must be caused; when the patients with XY chromosome complex show the female or intermediate phenotype, their Y chromosome or consequent targeting chromosomes must be damaged. The complicated mechanisms concerning the role of $\mathrm{Y}$ chromosome in gonadal differentiation and sex determination are best studied in XY sex reversal females. Male-to-female sex reversal giving rise to XY females with ambiguous genitalia, hypoplastic ovaries, or complete gonadal dysgenesis is the result of failure in testis determination or differentiation due to mutations or dosage alterations of genes from the testis determination pathway. Affected subjects with normal Müllerian structures and female genitalia and pure gonadal dysgenesis are subsumed under Swyer syndrome (McKusick, 1998). They are not diagnosed before puberty. In puberty, girls with pure gonadal dysgenesis neither develop secondary sexual characteristic nor do they menstruate. Patients with pure XY gonadal dysgenesis lack testicular development, are of normal stature (in contrast to Turner syndrome patients), and they do not show any additional extragenital symptoms. For male-to-female sex reversal with gonadal dysgenesis about fifteen candidate genes have been reported. Their temporal and spatial expression pattern and their mutual interaction have led to an arrangement of some of them in a hypothetical pathway of sex determination and differentiation (Veitia et al., 2001). The best known of these genes is the SRY gene (sex-determination region on the $\mathrm{Y}$ chromosome), the key determinant for testis formation from the undifferentiated bipotent gonad (Sinclair et al., 1990; Parker et al., 1999). More than 30 mutations have been described in SRY gene that triggers the testis-determining cascade. Mutations in SRY are detected in 15 to $20 \%$ of $46, \mathrm{XY}$ females with complete or partial gonadal dysgenesis (McElreavey, 1996). Many publications report affected relatives, most of them being two sisters. Sex-reversal mutation analysis in a unique family with three affected sisters was recently reported by us (Just et al., 2007). We excluded mutation in SRY and flanking sequences, also in seven other candidate genes. Since the pedigree suggests an X-chromosomal mode of inheritance, we assume that there is either another yet unknown gene in common for all three sisters within the interval on $\mathrm{Xp}$ that may cause Swyer syndrome or, more likely, that a gene in this interval is aberrantly regulated during gonad differentiation. Our data do not formally exclude another autosomal gene.

The $\mathrm{Y}$ chromosome in $\mathrm{X} / \mathrm{XY}$ chromosome mosaics is frequently damaged, and these aberrations lead to postzygotic nondisjunction causing chromosome mosaicism. Microdeletions of the Y chromosome may be associated with Y chromosome instability leading to formation of ambiguous genitalies. When the short arm of $\mathrm{Y}$ is deleted, then the SRY gene is undoubtedly lost (for example, the dicentric Y chromosome is not a rare accident, as found in our patient 8). Also, microanomalies of $\mathrm{Y}$ are found in these patients (Mancilla et al., 2003; Mazzanti et al., 2005). The frequency of Turner syndrome patients possessing an overt $\mathrm{Y}$ chromosome, as mentioned above, does not exceed a few per cent. When molecular markers are used for detection of $\mathrm{Y}$ chromosome material inserted into other chromosomes, the frequency of Y-containing Turner syndrome patients increases to 30 or more per cent (Mendes et al., 1999). Direct sequencing of the SRY gene shows the absence of mutations in this region and suggests that there are other genes playing an important role in sex development (AlvarezNava et al., 2003; Canto et al., 2004). The absence of mutations in the SRY gene might sometimes explain why virilisation and ambiguous genitalia are met in $\mathrm{X} / \mathrm{XY}$ mosaics much more frequent than in Swyer syndrome patients.

The other phenomenon, gonadoblastoma, which is regularly met in Swyer syndrome females but not in 45, X Turner syndrome patients, is usually an accident in 45,X/46, XY mosaics. The presence of $\mathrm{Y}$ chromosome material in patients with Turner syndrome is a risk factor for the development 
of gonadoblastoma - ovarial benign tumour, which has considerable malignant potential. The tumour risk has been estimated as more than 30\% (Verp and Simpson, 1987), although other studies suggest only 7-10\% (Gravholt et al., 2000). Bilateral gonadectomy remains the procedure of choice to exclude malignancy with absolute certainty. The supposed gonadoblastoma gene has been mapped to the pericentromeric region of the $\mathrm{Y}$ chromosome; therefore, its deletion causing the loss of the SRY gene is likely not as frequent as in distal parts of chromosome.

\section{REFERENCES}

Alvarez-Nava, F., Soto, M., Martinez, M.C., Prieto, M., Alvarez, Z. (2003). FISH and PCR analyses in three patients with $45, \mathrm{X} / 46, \mathrm{X}$ idic(Y) karyotype: Clinical and pathologic spectrum. Ann. Genet., 46(4), 443-448.

Canto, P., Galicia, N., Soderlund, D., Escudero, I., Mendez, J.P. (2004). Screening for mutations in the SRY gene in patients with mixed gonadal dysgenesis or with Turner syndrome and Y mosaicism. Eur. J. Obstet. Gynecol. Reprod. Biol., 115(1), 55-58.

Cotinot, C., Pailhoux, E., Jaubert, F., Fellous M. (2002). Molecular genetics of sex determination. Semin. Reprod. Med., 20(3), 157-167.

Gravholt, C.H., Fedder, J., Naeraa, R.W., Muller, J. (2000). Occurrence of gonadoblastoma in females with Turner syndrome and $\mathrm{Y}$ chromosome material: A population study. J. Clin. Endocrinol. Metab., 85, 3199-3202.

Heikkila, M., Peltoketo, H., Vainio, S. (2000). Genetic regulation of female development: Lessons from Wnt-4. In: Saenger, P. and Pasquino, A.M. (eds.). Optimizing Health Care for Turner Patients in the 21st Century. (pp. 29-49). Elsevier.

Hiort, O., Holterhus, P.M. (2000). The molecular basis of male sexual differentiation. Eur. J. Endocrinol., 142, 101-110.

Hossain, A., Saunders, G.F. (2001). The human sex-determining gene SRY is a direct target of WT1. J. Biol. Chem., 276 (20), 16817-16823.

Hsieh, Y.Y., Lin, W.C., Chang, C.C., Tsai, F.J., Yu, M.T., Tsai, H.D., Tsai, C.H. (2002). Turner syndrome with pseudodicentric $Y$ chromosome mosaicism. J. Assoc. Reprod. Genet., 19(6), 302-303.

Hsu, L.Y.F. (1994). Phenotype/kariotype correlations of Y chromosome aneuploidy with emphasis on structural aberrations in postnatally diagnosed cases. Amer. J. Med. Genet., 53, 108-140.

Idzelienè, I., Razbadauskas, A., Andriuškevičiūtè, I., Jurkẻnienè, L., Šalomskienè, L., Sinkus, A. (2005). The inherited Robertsonian 13q14q translocation and sex chromosome aneuploidies in the same family. Biologija (Vilnius), 4, 19-23.

Just, W., Sinkus, A., Baumstark, A., Kuhn, R., Ortmann, D., Andriuškevičiūtė, I., Jurkẻnienè, L., Šalomskienè, L. (2007). Sex reversal mutation analysis in a family with pure gonadal dysgenesis of XY female type. Biologija (Vilnius), 3, 16-24.

Kučinskas, L., Just, W. (2005). Human male sex determination and sexual differentiation: pathways, molecular interactions and genetic disorders. Medicina (Kaunas), 41 (8), 633-640.

Manzilla, E.E., Poggi, H., Repetto, G., Rumie, H., Garcia, H., Ugarte, F., Hidalgo, S., Jara, A., Muzzo, S., Panteon, E., Torrealba, I., Foradori, A., Cattani, A. (2003) Y chromosome sequences in Turner's syndrome: Association with virilization and gonadoblastoma. J. Pediatr. Endocrinol. Metab., 16(8), 1157-1163.

Mazzanti, L., Cicognani, A., Baldazzi, L., Bergamashi, R., Scarano, E., Strocchi, E., Nicoletti, A., Mencarelli, F., Pittalis, M., Forabosco, A., Caciari, E. (2005). Gonadoblastoma in Turner syndrome and Y-chromosome-derived material. Amer. J. Med. Genet. 135(2), 150-154.

McElreavey, K. (1996). Mechanism of sex determination in mammals. Adv. Genome Biol., 4, 304-354.

McKusick, V.A. (1998). OMIM (Online Mendelian Inheritance in Man). Catalogs of Human Genes and Genetic Disorders. Baltimore, John Hopkins Univ. Press, \#306100.

Mendes, J.R.T., Strufaldi, M.W.L., Delcelo, R., Moises, R.C.M.S., Vieira, J.G., Kasamatsu, T.S., Galera, M.F., Andrade, J.A.D., Verreshi, I.T.N. (1999). Y-chromosome identification by PCR and gonadal histopathology in Turner's syndrome without overt Y-mosaicism. Endocrinology, 50, $19-26$.

Parker, K.L., Schimmer, B.P., Schedl, A. (1999). Genes essential for early events in gonadal development. Cell. Mol. Life Sci., 55, 831-838.

Reddy, K.S., Sulcova, V. (1998). Pathogenesis of 45,X/46,XY gonadal mosaicism. Cytogenet. Cell. Genet., 82(1-2), 52-57.

Rooney, D.E. (ed.) (2001). Human cytogenetics: Constitutional analysis. A practical approach. Oxford: Oxford. Univ. Press, 3rd. ed., 282 p.

Sinclair, A.H., Berta, P., Palmer, M.S., Hawkins, J.R., Griffiths, B.L., Smith, M.J., Foster, J.W., Frischauf, A.M., Lovell-Badge, R., Goodfellow, P.N. (1990). A gene from the human sex-determining region encodes a protein with homology to a conserved DNA-binding motive. Nature, 346, 240-244.

Su, H., Lau, Y-F.C. (1993). Identification of the transcriptional unit, structural organization, and promoter sequence of the human sex-determining region Y (SRY) gene, using a reverse genetic approach. Amer. J. Hum. Genet., 52, 24-38.

Veitia, R.A., Salas-Cortes, L., Ottolenghi, C., Pailhoux, E., Cotinot, C., Fellous, M. (2001). Testis determination in mammals: more questions than answers. Mol. Cell. Endocrinol. 179, 3-16.

Verp, M.S., Simpson, J.L. (1987). Abnormal sexual differentiation and neoplasia. Cancer Genet. Cytogenet., 25, 191-218.

Received 20 October 2008

\section{X/XY HROMOSOMU MOZAĪCISMS: TĒRNERA SINDROMS UN CITI KLĪNISKIE STĀVOKL̨I}

Hromosomu mozaīcisms 45,X/46,XY klīniski izpaužas ar plašu fenotipa spektru, kas svārstās no sievietes ar Tērnera sindromu, vīrišķā vai sievišķāa pseidohermafrodītisma līdz normāli attīstītam vīrietim. Tērnera sindromam raksturīgās hromosomu anomālijas tika atrastas 236 pacientu limfocītu kultūrās. 118 (50\%) pacientiem kariotips bija 45,X. Monosomijas X mozaīcisms vai struktūras izmainas X hromosomā tika konstatētas $112(47,4 \%)$ pacientiem ar Tērnera sindromam tipiskām pazīmēm. Piecās 45,X/46,XY mozaīkās proporcija XY klonam variēja no $46 \%$ līdz 76\%. Vienā Tērnera sindroma gadījumā atrada tikai 47,XYY šūnu līniju (izmeklējumi veikti tikai asins kultūrā). Uzskata, ka vairumā 45,X/46,XY mozaīcisma gadījumu cēlonis varētu būt Y hromosomas zudums neatiešanas dēl pēc normālas disomiskas apaugḷošanas. Neatiešanu, iespējams, veicina $\mathrm{Y}$ hromosomas aberācijas un mikroanomālijas. Pārējiem pieciem pacientiem ar X/XY hromosomu mozaīcismu bija jaukta gonādu disğenēze (2), vīrišḳais pseidohemafrodītisms (1), Pjēra Robina sindroms (1 vīrietis) un normāls vīrieša fenotips (1). Diviem pacientiem, kuriem nebija Tērnera sindroma, mozaīcisms 45,X/46,XY/47,XYY, iespējams, izveidojās sakarā ar Y hromosomas neatiešanu, daloties primārajam klonam 46,XY; vienam pacientam bija dicentriska Y hromosoma. Tiek apskatīta līdzība starp Tērnera sindromu ar 45,X/46,XY mozaīcismu un Swyer sindromu. SRY gēna mutācijas pie Tērnera sindroma mozaīcisma nav atrastas, bet ir palielināta saslimstība ar gonadoblastomu. 